\title{
Article \\ Photodynamic Inactivation of Legionella pneumophila Biofilm Formation by Cationic Tetra- and Tripyridylporphyrins in Waters of Different Hardness
}

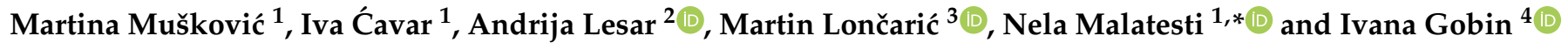 \\ 1 Department of Biotechnology, University of Rijeka, Radmile Matejčić 2, 51000 Rijeka, Croatia; \\ martina.muskovic@biotech.uniri.hr (M.M.); iva.cavar@student.uniri.hr (I.Ć.) \\ 2 Bioinstitut d.o.o., R. Steinera 7, 40000 Čakovec, Croatia; lesar@bioinstitut.hr \\ 3 Photonics and Quantum Optics Unit, Center of Excellence for Advanced Materials and Sensing Devices, \\ Ruđer Bošković Institute, Bijenička Cesta 54, 10000 Zagreb, Croatia; martin.loncaric@irb.hr \\ 4 Department of Microbiology and Parasitology, Faculty of Medicine, University of Rijeka, Braće Branchetta 20, \\ 51000 Rijeka, Croatia; ivana.gobin@medri.uniri.hr \\ * Correspondence: nela.malatesti@biotech.uniri.hr; Tel.: +385-51-584-585; Fax: +385-51-584-599
}

check for

updates

Citation: Mušković, M.; Ćavar, I.; Lesar, A.; Lončarić, M.; Malatesti, N.; Gobin, I. Photodynamic Inactivation of Legionella Pneumophila Biofilm Formation by Cationic Tetra- and Tripyridylporphyrins in Waters of Different Hardness. Int. J. Mol. Sci. 2021, 22, 9095. https://doi.org/ $10.3390 /$ ijms 22169095

Academic Editor: Giovanna Batoni

Received: 31 July 2021

Accepted: 20 August 2021

Published: 23 August 2021

Publisher's Note: MDPI stays neutral with regard to jurisdictional claims in published maps and institutional affiliations.

Copyright: (c) 2021 by the authors. Licensee MDPI, Basel, Switzerland. This article is an open access article distributed under the terms and conditions of the Creative Commons Attribution (CC BY) license (https:// creativecommons.org/licenses/by/ $4.0 /)$.

\begin{abstract}
The bacterium Legionella pneumophila is still one of the probable causes of waterborne diseases, causing serious respiratory illnesses. In the aquatic systems, L. pneumophila exists inside freeliving amoebae or can form biofilms. Currently developed disinfection methods are not sufficient for complete eradication of L. pneumophila biofilms in water systems of interest. Photodynamic inactivation (PDI) is a method that results in an antimicrobial effect by using a combination of light and a photosensitizer (PS). In this work, the effect of PDI in waters of natural origin and of different hardness, as a treatment against L. pneumophila biofilm, was investigated. Three cationic tripyridylporphyrins, which were previously described as efficient agents against L. pneumophila alone, were used as PSs. We studied how differences in water hardness affect the PSs' stability, the production of singlet oxygen, and the PDI activity on L. pneumophila adhesion and biofilm formation and in biofilm destruction. Amphiphilic porphyrin showed a stronger tendency for aggregation in hard and soft water, but its production of singlet oxygen was higher in comparison to tri- and tetracationic hydrophilic porphyrins that were stable in all water samples. All three studied porphyrins were shown to be effective as PDI agents against the adhesion of the L. pneumophila to polystyrene, against biofilm formation, and in the destruction of the formed biofilm, in their micromolar concentrations. However, a higher number of dissolved ions, i.e., water hardness, generally reduced somewhat the PDI activity of all the porphyrins at all tested biofilm growth stages.
\end{abstract}

Keywords: porphyrins; disinfection; Legionella pneumophila; biofilm; water hardness; singlet oxygen

\section{Introduction}

Photodynamic therapy (PDT) is used to treat various oncological and nononcological diseases by generating cytotoxic single oxygen $\left({ }^{1} \mathrm{O}_{2}\right)$ and other reactive oxygen species (ROS) at the site of light activation of a photosensitizer (PS) molecule [1]. Antibacterial photodynamic therapy (aPDT), also familiar under the name of photodynamic inactivation (PDI), can be used against various pathogens, so far mostly tested on Escherichia coli and Staphylococcus aureus [2,3], and for treating various infections, such as wound infections, acne, and periodontal diseases [4,5].

Some of the advantages of PDI over other antimicrobial therapies include the wide range of potential PSs that can be used, the limited toxicity of the treatment, and a low possibility to develop resistance to this therapy, due to its nonselective mode of action and reacting with lipids, proteins, and nucleic acids as part of the different biomolecular targets [5]. The rapidly growing field of application of PDI in disinfection and against 
biofilms includes the treatments of topical infections [6], oral biofilms in dentistry [7,8], and biofilms on prosthetic material/implants [9].

It is well known from the literature and research so far that all PSs, neutral, anionic, and cationic, can be effective against Gram-positive bacteria; however, only positively charged PSs seem to be effective alone against Gram-negative bacteria. This group of bacteria has two membranes separated by a peptidoglycan-containing periplasm, and so the outer membrane forms a barrier that can block many PSs from binding [10]. In the case of anionic or neutral PSs, outer membrane disrupting agents, such as ethylenediaminetetraacetic acid and calcium chloride, are necessary to enable their photodynamic action against Gram-negative bacteria [11]. It has been proposed that cationic porphyrins undergo a "self-promoted uptake pathway", a mechanism that includes the electrostatic interaction with the outer membrane and results in its weakening, which increases the binding of the PS to the bacteria, enhancing the PDI activity without a pretreatment with "membrane softeners" [12].

Legionella pneumophila is a Gram-negative bacterium and a member of the class of opportunistic premise plumbing pathogens (OPPPs), a group of pathogens with common features that include the formation of biofilms and resistance to commonly used disinfection approaches such as the use of thermal treatment, chlorination, and biocides. Other OPPPs that pose a danger to human health include Mycobacterium spp. and Pseudomonas aeruginosa [13].

Legionellae, in water systems, mostly develop inside free-living amoebae or biofilms [14]. Biofilm, as an organized aggregate of microorganisms, can provide shelter from various antibiotics and a supply of nutrients for growth [15]. It was shown that L. pneumophila can adhere and form a biofilm on different materials, including plastic and stainless steel; however, some other materials such as copper may be used to inhibit adhesion [16]. Some physicochemical properties that can induce L. pneumophila biofilm formation are the stagnation of the water, the availability of the carbon that provides nutrients, and bivalent cations such as $\mathrm{Mg}^{2+}$ and $\mathrm{Ca}^{2+}$ that were shown to ease the attachment of the L. pneumophila to various materials [17].

Several treatments have been tested in the eradication of L. pneumophila biofilm, such as chlorination; use of phages; control of the carbon sources; or the use of the nanoparticles, different surfactants, antimicrobial peptides, or essential oils. However, none of these treatments induced a complete elimination, since the recolonization of the bacterium occurred in a short time after the end of the treatment [18].

In our previous work, three cationic pyridylporphyrins were investigated against L. pneumophila in the local tap water. All three porphyrins showed high PDI activity at low minimal effective concentration (MEC), but the highest activity, in concentration $<0.1 \mu \mathrm{M}$, was shown with a tricationic porphyrin bearing a long alkyl chain, TMPyP3- $\mathrm{C}_{17} \mathrm{H}_{35}$ [19]. L. pneumophila strain 130b was used for all our previous studies; however, due to the increase in passages in laboratory conditions, phenotypic changes occurred, so for the biofilm studies, we used the clinical isolate of L. pneumophila Philadelphia strain, which is a common clinical isolate in Europe and the world. The difference between these two strains is not very well known, but it is possible that they differ in the lipopolysaccharide component of the outer membrane [20].

A higher amount of cations dissolved in water can positively affect the biofilm formation, due to salt precipitation and scale formation that facilitate L. pneumophila adhesion, and it also may improve colonization of biofilms by the bacteria [17]. In our previous work, we have observed small spectroscopic changes of tested porphyrins in tap water [19]; thus, we wanted to investigate in more detail the impact of water hardness on our porphyrins and their antibacterial activity. Herschmann et al., for example, investigated the physicochemical properties of tetracationic pyrid-4-ylporphyrin and its activity against E. coli in presence of various monovalent and bivalent cations [21]. They observed a high impact on singlet oxygen production and PDI only in presence of toxic metals; however, 
this motivated us to investigate the effect of ions naturally present in the raw groundwater in the treatment against L. pneumophila by PDI.

Therefore, the aim of our work that we present here was to investigate further the PDI potential of cationic PSs in Legionella control and their antibiofilm properties by investigating the PDI activity of the three above-mentioned cationic porphyrins in water samples of different hardness. As far as we know, this is the first study of the photodynamic effect on Legionella biofilm.

\section{Results and Discussion}

\subsection{Physicochemical Properties of Water Samples}

In our previous paper, we presented results that showed the high antibacterial efficacy of three cationic pyridylporphyrins and PDI against L. pneumophila in tap water and thus their significant potential for water treatments to control Legionella [19]. Therefore, we wanted to investigate further this potential, as well as the effects of PDI on L. pneumophila biofilm in water, using samples taken directly from the water wells. The idea was to investigate the effect of these compounds on the Legionella biofilm, with and without light activation of the PSs, in the raw groundwater and to examine the influence of the minerals present in different water samples in different amounts.

The main difference between the three different types of water used in this work was in the amount of calcium and magnesium ions dissolved in water, i.e., in the hardness of the water. Water hardness is usually described by the amount of dissolved calcium carbonate $\left(\mathrm{CaCO}_{3}\right)$ in water, although other multivalent or divalent ions dissolved, such as, iron, barium, and zinc, can be taken into an account [22]. Water samples from water wells in Nedelišće and Prelog, two locations in Međimurska County (Croatia), were used as such without further manipulation; only a filter sterilization was performed before the use in experiments on L. pneumophila and adding the bacterium. The water sample from the water well in Prelog, with $403 \mathrm{mg} / \mathrm{L} \mathrm{CaCO}_{3}$ dissolved, was throughout our studies considered as hard water (HW), while the water sample from the water well in Nedelišce, with $231 \mathrm{mg} / \mathrm{L} \mathrm{CaCO}_{3}$ dissolved, was considered as soft water (SW). Demineralized water (DEMI) was used as a control, with a negligible amount of dissolved minerals (Table 1).

Table 1. General properties of the water samples used in this work. Soft water (SW) and hard water (HW) were taken from water wells in Nedelišće and Prelog in Međimurska County (Croatia).

\begin{tabular}{cccc}
\hline Title $\mathbf{1}$ & \multicolumn{3}{c}{ Water Samples } \\
\hline & DEMI & SW & HW \\
\hline $\mathrm{CaCO}_{3}(\mathrm{mg} / \mathrm{L})^{\mathrm{a}}$ & $/$ & 231 & 403 \\
$\mathrm{pH}^{\mathrm{a}, \mathrm{b}}$ & 7.00 & 7.66 & 7.43 \\
${\text { Conductivity }(\mathrm{S} / \mathrm{cm})\left(\mathrm{t}=20^{\circ} \mathrm{C}\right)^{\mathrm{b}}}_{\mathrm{Cl}^{-}(\mathrm{mg} / \mathrm{L})^{\mathrm{a}}}$ & 4 & 403 & 678 \\
$\mathrm{~K}^{+}(\mathrm{mg} / \mathrm{L})^{\mathrm{a}}$ & $/$ & 8.53 & 20.08 \\
$\mathrm{Na}^{+}(\mathrm{mg} / \mathrm{L})^{\mathrm{a}}$ & $/$ & 1.7 & 1.8 \\
$\mathrm{Mg}^{2+}(\mathrm{mg} / \mathrm{L})^{\mathrm{a}}$ & $/$ & 5.1 & 5.2 \\
$\mathrm{Ca}^{2+}(\mathrm{mg} / \mathrm{L})^{\mathrm{a}}$ & $/$ & 7.7 & 23.3 \\
$\left.\mathrm{Hardness}^{\mathrm{m} g / \mathrm{L}}\right)^{\mathrm{a}}$ & $/$ & $/$ & 112.0 \\
${\text { Oxygen levels (mg } / \mathrm{L})^{\mathrm{b}}}^{\mathrm{b}}$ & 0.2 & 240 & 396 \\
\hline
\end{tabular}

a Parameters measured in the laboratory of Međimurske vode d.o.o. ${ }^{\mathrm{b}}$ Parameters measured using HQ30D Flexi meter with changing probes.

\subsection{Spectroscopic Properties of the Tested PSs in Waters of Different Hardness}

The spectroscopic properties of TMPyP3, TMPyP3- $\mathrm{CH}_{3}$, and TMPyP3- $\mathrm{C}_{17} \mathrm{H}_{35}$ (Figure 1) were measured in water samples that contained different amounts of dissolved minerals (denoted as DEMI, SW, and HW). In the absorption spectra obtained in DEMI with all the compounds, there is a strong Soret band (with the molar absorption coefficients $\varepsilon \sim 250 \times 10^{4} \mathrm{M}^{-1} \mathrm{~cm}^{-1}$ ) at $416 \mathrm{~nm}$ for TMPyP3, at $418 \mathrm{~nm}$ for TMPyP3- $\mathrm{CH}_{3}$, and at 
$420 \mathrm{~nm}$ for TMPyP3- $\mathrm{C}_{17} \mathrm{H}_{35}$, and there are four $\mathrm{Q}$ bands from 500 to $650 \mathrm{~nm}$. Q bands, which are normally seen as four defined sharp peaks in the spectra obtained in $\mathrm{MeOH}$, here can be seen as a "stretched and broad" peak, which we observed also in our previous work where we tested these porphyrins in the tap water $[19,23]$. In the soft (SW) and hard (HW) water, small to negligible changes can be observed in the $Q$ bands for compounds TMPyP3 and TMPyP3- $\mathrm{CH}_{3}$ (Figure 2A,B). On the other hand, the absorption spectra of TMPyP3- $\mathrm{C}_{17} \mathrm{H}_{35}$ obtained in DEMI, SW, and HW show more significant differences in both Soret band and $\mathrm{Q}$ bands (Figure $2 \mathrm{C}$ ). The presence of minerals in water correlates with a decreasing intensity of the Soret band and its molar absorption coefficient (from $255 \times 10^{3}$ to $159 \times 10^{3} \mathrm{M}^{-1} \mathrm{~cm}^{-1}$ ) (Table S1), and a broadening of the Soret band occurs in SW and HW in comparison to DEMI. Besides a lower intensity, a small bathochromic shift can be seen for $Q_{y}(1-0)$ and $Q_{x}(1-0)$ electronic transitions. These changes in the absorption spectra may indicate the formation of nonspecific aggregates in the presence of dissolved minerals in water [24].

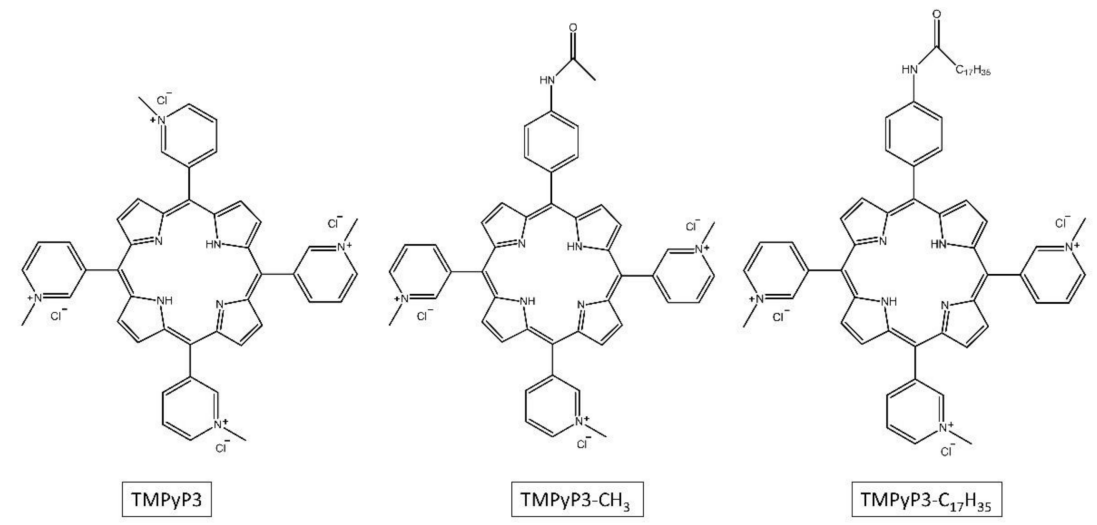

Figure 1. Structures of photosensitizers TMPyP3, TMPyP3- $\mathrm{CH}_{3}$, and $\mathrm{TMPyP} 3-\mathrm{C}_{17} \mathrm{H}_{35}$.

In the emission spectra, more significant differences can be seen in the fluorescence intensity for compounds TMPyP3- $\mathrm{C}_{17} \mathrm{H}_{35}$ and TMPyP3, while spectra for TMPyP3- $\mathrm{CH}_{3}$ show only small differences in different water samples at concentration $1 \mu \mathrm{M}$ (Figure 3). Again, the intensity in $\mathrm{SW}$ and $\mathrm{HW}$ is decreased for TMPyP3- $\mathrm{C}_{17} \mathrm{H}_{35}$ in comparison to DEMI, which confirms the possibility of aggregation, presumably due to the presence of a long alkyl chain. The TMPyP3 spectra show a mild decrease in fluorescence intensity when collected in SW; however, they show a strong decrease and thus a very low intensity in HW (Figure $3 \mathrm{~A}$ ). Considering the structure of the molecule, its symmetry and $\pi-\pi$ interactions may promote aggregation and consequently increase the fluorescence intensity, especially in the presence of ions such as in the SW and HW samples.

\subsection{Photostability of the PSs in Different Water Samples}

To investigate photostability, two 5-day-long experiments with repeated irradiation cycles (T1) and first-day-only irradiation cycles (T2) were carried out and compared to a nonirradiated sample that served as a control. A setup for irradiation, protected from external light, was used with an LED-based source of violet light $(411 \mathrm{~nm})$ and fluence rate $11 \mathrm{~mW} / \mathrm{cm}^{2}$ (Figure 4 ).

The results of the photostability measurements after 5-day experiment are shown here as a ratio of the absorbance on the first and last (fifth) days of the experiment $\left(\mathrm{A} / \mathrm{A}_{0}\right)$ (Figure 5) and over time (Figures S1-S3). For TMPyP3 in DEMI and SW, there are no noticeable differences in absorption, and more than $85 \%$ of the initial absorbance $\left(\mathrm{A}_{0}\right)$ remained in all the experiments (Figure 5A and Figure S1). A difference can be observed in the T1 experiment with the same PS in HW, where the sample was irradiated every day for $10 \mathrm{~min}$. This decrease is significant in comparison to the dark control and the T2 experiment, which indicates that repeated irradiation together with HW can somewhat affect the stability of the molecule. 

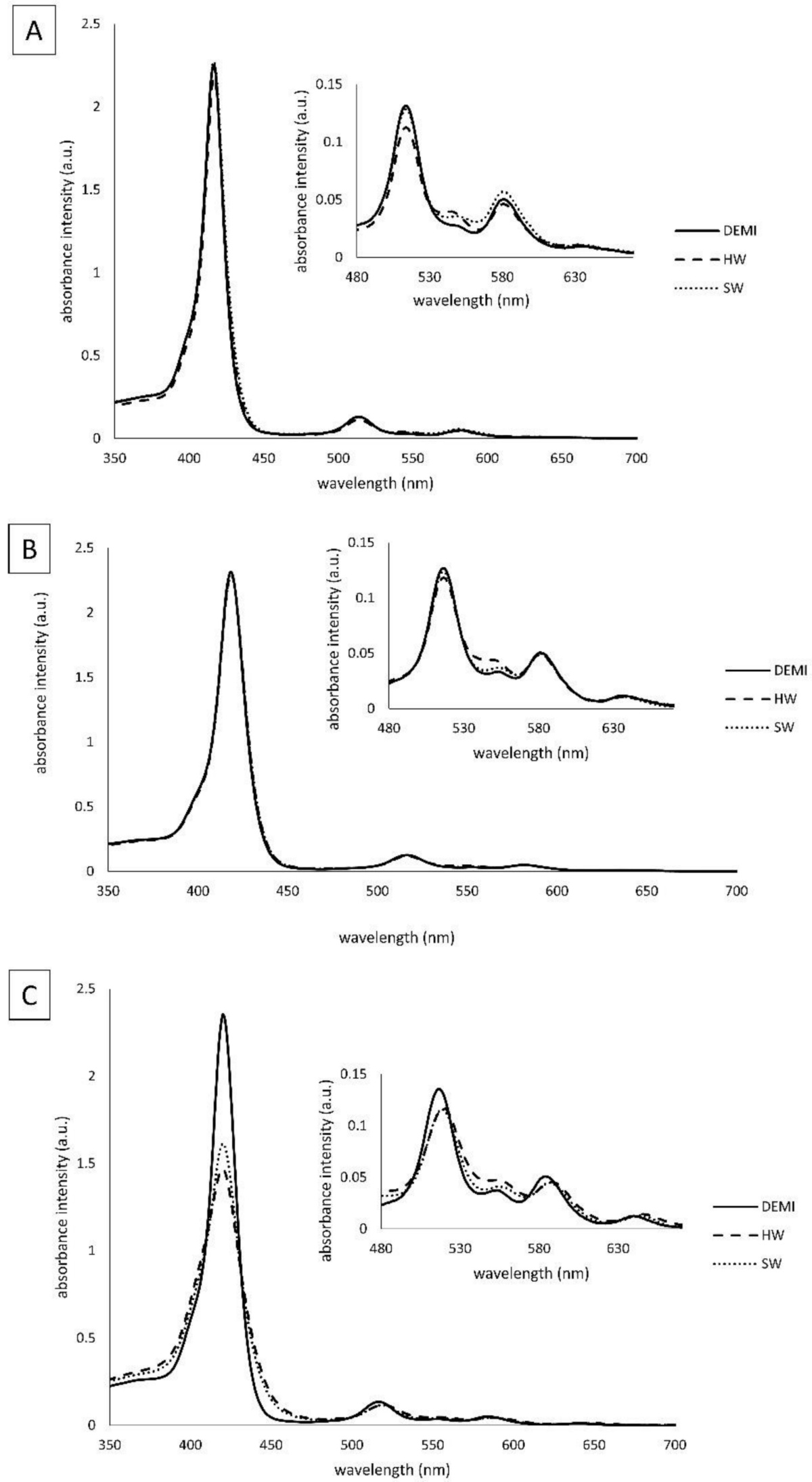

Figure 2. Absorption spectral characteristics of TMPyP3 (A), $\mathrm{TMPyP}_{3}-\mathrm{CH}_{3}$ (B), and $\mathrm{TMPyP}-\mathrm{C}_{17} \mathrm{H}_{35}$ (C) in DEMI (full line), soft water (dashed line), and hard water (dotted line). All measurements were performed in $10 \mu \mathrm{M}$ solutions. 

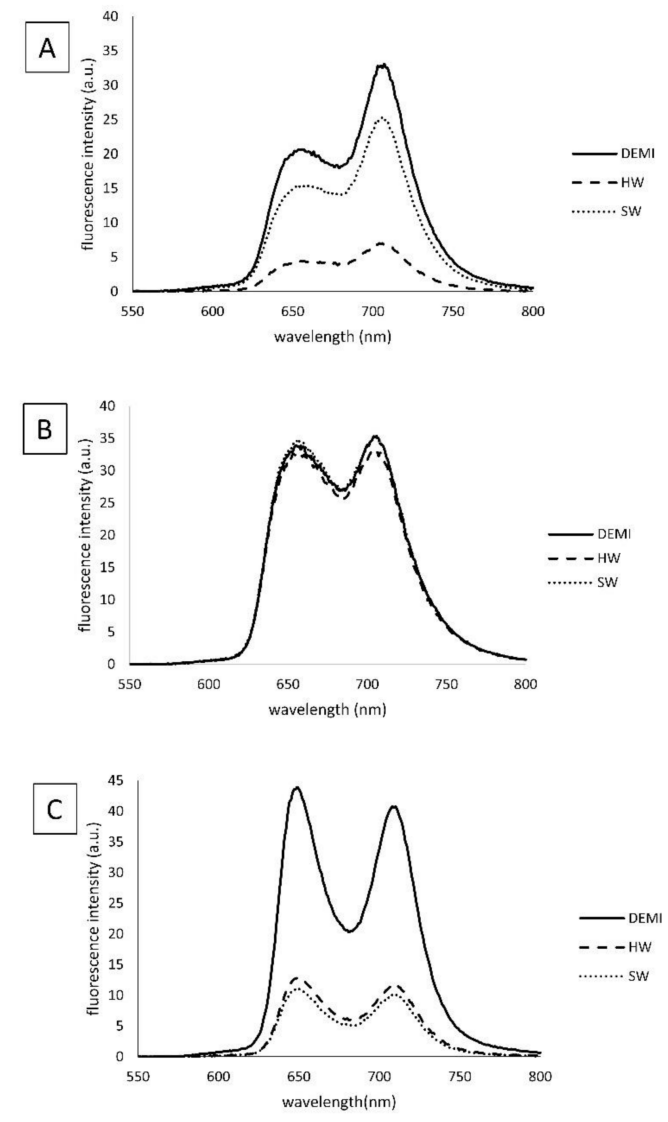

Figure 3. Fluorescence spectral characteristics of TMPyP3 (A), $\mathrm{TMPyP}_{-}-\mathrm{CH}_{3}$ (B), and TMPyP3$\mathrm{C}_{17} \mathrm{H}_{35}$ (C) in DEMI (full line), soft water (dashed line), and hard water (dotted line). All measurements were performed in $1 \mu \mathrm{M}$ solutions.
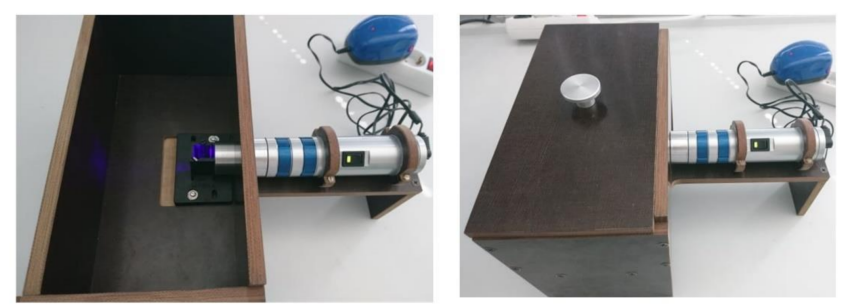

Figure 4. Illumination setup for the detection of singlet oxygen and photostability studies. The light source used is an LED-based source of violet light at $411 \mathrm{~nm}$, with interchangeable fluence rates (3.5, 7 , and $11 \mathrm{~mW} / \mathrm{cm}^{2}$ ).
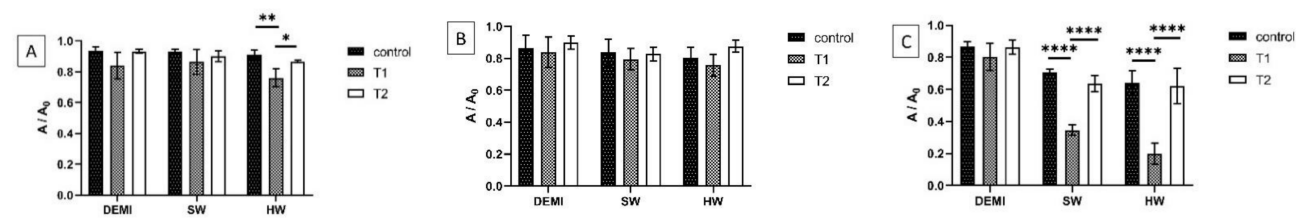

Figure 5. Photostability of TMPyP3 (A), TMPyP3- $\mathrm{CH}_{3}$ (B), and $\mathrm{TMPyP} 3-\mathrm{C}_{17} \mathrm{H}_{35}$ (C) measured in DEMI, SW, and HW. T1 represents a ratio of the absorbance recorded on the fifth and on the first day $\left(\mathrm{A} / \mathrm{A}_{0}\right)$ of $10 \mu \mathrm{M}$ PS solution that was irradiated for 10 min every $24 \mathrm{~h}$ for 5 days (411 $\mathrm{nm}$; total light dose $33 \mathrm{~J} / \mathrm{cm}^{2}$ ), while $\mathrm{T} 2$ represents $\mathrm{A} / \mathrm{A}_{0}$ after a 5-day-long experiment where each PS was irradiated for $10 \mathrm{~min}$ only the first day $\left(411 \mathrm{~nm}\right.$; total light dose $\left.6.6 \mathrm{~J} / \mathrm{cm}^{2}\right)$. Control represents PSs tested under the same conditions, protected from light. Data represent an average of triplicate measurements \pm standard deviation (SD); ${ }^{* * * *} p<0.0001,{ }^{* *} 0.001<p<0.01,{ }^{*} 0.01<p<0.05$. 
Most interesting, for TMPyP3- $\mathrm{C}_{17} \mathrm{H}_{35}$ only in DEMI, the water absorbance remained above $80 \%$ in both experiments and in the control (Figure 5C and Figure S3). The impact of repeated irradiation in comparison to one-time irradiation can be seen both in SW and HW, where the percentage of the initial absorbance in SW was $27 \%$ for T1 and $58 \%$ for T2, while in HW, it was $20 \%$ and $58 \%$ for $\mathrm{T} 1$ and $\mathrm{T} 2$, respectively. The impact of dissolved ions in water on the stability of this PS can be clearly seen in the increasing absorbance from DEMI to SW and mostly in HW. For example, control in DEMI stayed above $86 \%$, while it was $70 \%$ in SW and HW; in T2, in DEMI, the water percentage of the absorbance intensity was again above $80 \%$, while in both SW and HW, it was $~ 58 \%$ (Figure $5 \mathrm{~A}$ ).

For TMPyP3- $\mathrm{CH}_{3}$, no significant difference was observed, with all the absorbance intensities above $80 \%$ of $\mathrm{A}_{0}$ after 5 days of experiments in all water samples (Figure $5 \mathrm{~B}$ and Figure S2), indicating the greatest photostability among all tested PSs, even in the presence of minerals. Considering the correlation of these results with the emission spectra shown in Figure 3, the decrease in (photo)stability of the tested compounds can be related to a higher tendency for aggregation.

\subsection{Singlet Oxygen Production}

To investigate the impact of water hardness on the production of singlet oxygen, the photodegradation of 9,10-anthracenediyl-bis(methylene)dimalonic acid (ABMDMA) was used. ABMDMA is known as a fluorescent dye that is soluble in water, but with a low reactivity, and it can capture only $2 \%$ of the produced singlet oxygen [25]. However, it is highly specific for singlet oxygen as opposed to other reactive oxygen species (ROS). In contrast, 1,3-diphenylisobenzofurane (DPBF), which is often used as a fluorescent probe in the measurements of the singlet oxygen production, reacts with the various ROS [26,27]. Here, we used the method modified from our previous work, where we used non-watersoluble 9,10-dimethylantracene (DMA) [28]. ABMDMA was used in a concentration of $6 \mu \mathrm{M}$, mixed with a $1 \mu \mathrm{M}$ concentration of the PSs, and then irradiated for $10 \mathrm{~min}(411 \mathrm{~nm}$, fluence rate $7 \mathrm{~mW} / \mathrm{cm}^{2}$, light dose $4.2 \mathrm{~J} / \mathrm{cm}^{2}$ ).

Interestingly, with TMPyP3- $\mathrm{C}_{17} \mathrm{H}_{35}$ (Figure $6 \mathrm{C}$ and Figure $\mathrm{S6}$ ), a strong decrease in the ABMDMA fluorescence ( $>80 \%$ in all water samples) could be observed in comparison to TMPyP3 and TMPyP3- $\mathrm{CH}_{3}$, which showed small to medium effect ( 20\%) (Figure $6 \mathrm{~A}, \mathrm{~B}$ ). A higher production of singlet oxygen for those two PSs was observed only in their higher concentrations, above $3 \mu \mathrm{M}$ (data not shown).

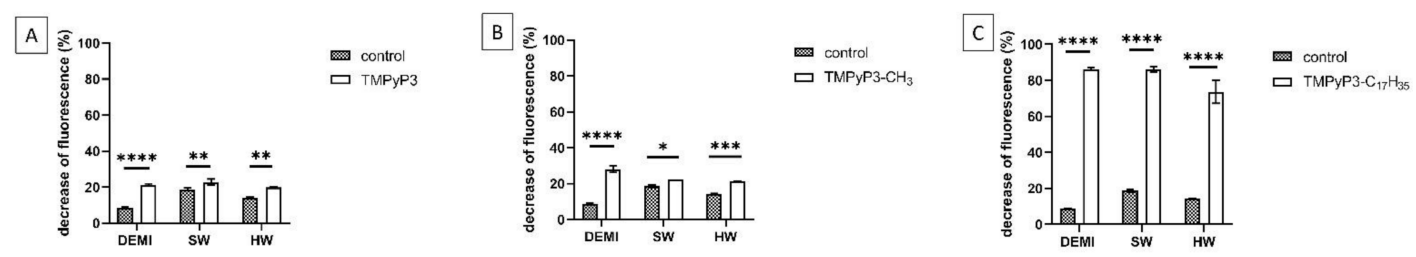

Figure 6. Singlet oxygen production of TMPyP3 (A), $\mathrm{TMPyP} 3-\mathrm{CH}_{3}(\mathbf{B})$, and $\mathrm{TMPyP}_{3}-\mathrm{C}_{17} \mathrm{H}_{35}(\mathbf{C})$ in different water samples (DEMI, SW, HW) (1 $\mu$ M solution) measured by photodegradation of 9,10-anthracenediyl-bis(methylene)dimalonic acid (ABMDMA) $(6 \mu \mathrm{M})$ after $10 \mathrm{~min}$ irradiation $\left(411 \mathrm{~nm}\right.$, fluence rate $3.5 \mathrm{~mW} / \mathrm{cm}^{2}$, total light dose $\left.2.1 \mathrm{~J} / \mathrm{cm}^{2}\right)$. The photodegradation of ABMDMA without the presence of PSs in different water samples was used as a control. Data on graphs are presented as a measurement average, with error bars presenting SD; ${ }^{* * *} p<0.0001,{ }^{* * *} 0.0001<p<0.001$, ${ }^{* *} 0.001<p<0.01,{ }^{*} 0.01<p<0.05$.

One of the possible reasons for the observed effect could be the amphiphilicity of TMPyP3- $\mathrm{C}_{17} \mathrm{H}_{35}$ due to the hydrophilic moiety based on tricationic pyridinium units and highly lipophilic moiety based on the long alkyl chain on the remaining aryl group in the porphyrin meso position. An unusual aggregation in water and formation of vesicles were previously described for an amphiphilic porphyrin with a similar structure [29]. Therefore, one possibility is that such aggregates may capture molecules of ABMDMA, consequently increasing the reaction of ABMDMA with singlet oxygen and the formation 
of nonfluorescent endoperoxide. Although it is known that aggregates usually decrease the singlet oxygen production in all solvents, a similar effect was shown by Rapozzi et al., who showed a dramatic decrease in pheophorbide A $(\mathrm{PPa})$ singlet oxygen production in the phosphate buffer $(\phi<0.01)$; however, the singlet oxygen production was high inside the liposomes and cells [30]. A higher production of ROS can have an impact on the stability of the molecule [31], so this could explain together the observed high production of singlet oxygen for TMPyP3- $\mathrm{C}_{17} \mathrm{H}_{35}$ and low photostability of the molecule, especially in cases of repeated irradiation of the solution.

The impact of the water hardness on the singlet oxygen production by PDT with TMPyP3 and TMPyP3- $\mathrm{CH}_{3}$ could not be noticed, due to the small production of singlet oxygen in tested PS concentration. A lower ${ }^{1} \mathrm{O}_{2}$ production in $\mathrm{HW}$, in comparison to SW and DEMI, can be observed for TMPyP3- $\mathrm{C}_{17} \mathrm{H}_{35}$, where the percentage of the fluorescence decrease was $73 \%$, while it was around $86 \%$ in DEMI and SW. A higher light dose did not show a significant increase in singlet oxygen production for TMPyP3 or TMPyP3- $\mathrm{CH}_{3}$ (Figures S4 and S5).

According to the results of photostability and singlet oxygen production, as well as our previous results, it can be concluded that the amphiphilic TMPyP3- $\mathrm{C}_{17} \mathrm{H}_{35}$ is highly potent PS for PDI; however, it has a higher tendency for aggregation in the presence of various minerals dissolved in water, and its stability is strongly decreased, especially by repeated illumination with violet light. In contrast, both hydrophilic porphyrins (TMPyP3 and TMPyP3- $\mathrm{CH}_{3}$ ) showed higher stability for a long time, with and without light irradiation, and can possibly produce singlet oxygen in higher concentrations.

2.5. Minimal Effective Concentrations (MECs) and Photoinactivation (PDI) Studies of the PSs on Legionella pneumophila

To determine the antibacterial activity of the PSs on L. pneumophila in different water samples, we determined the minimal effective concentrations (MECs), with and without irradiation, in these waters (Table 2). We also carried out (photo)inactivation studies using PSs against L. pneumophila, with and without irradiation (Figure 7).

Table 2. Minimal effective concentration (MEC) of TMPyP3, TMPyP3- $\mathrm{CH}_{3}$, and $\mathrm{TMPyP} 3-\mathrm{C}_{17} \mathrm{H}_{35}$ determined in DEMI after irradiation for $10 \mathrm{~min}$ with violet light $\left(395 \mathrm{~nm}, 12 \mathrm{~J} / \mathrm{cm}^{2}\right)$.

\begin{tabular}{cccc}
\hline & & \multicolumn{3}{c}{ MEC $(\boldsymbol{\mu M})$} \\
\hline \multirow{2}{*}{ TMPyP3 } & & Dark & $\lambda=\mathbf{3 9 5} \mathbf{~ n m}$ \\
& DEMI & 6.250 & 3.125 \\
& SW & $>5$ & 6.250 \\
TMPyP3-CH 3 & HW & $>25$ & 12.50 \\
& DEMI & 3.125 & 0.780 \\
& SW & $>5$ & 3.125 \\
\multirow{2}{*}{ TMPyP3-C $_{17} \mathrm{H}_{35}$} & HW & $>25$ & 6.250 \\
& DEMI & 3.125 & 0.780 \\
& SW & 6.250 & 3.125 \\
& HW & $>25$ & 6.250 \\
\hline
\end{tabular}

From the obtained results, the MEC values increase for all PSs, under irradiation or without irradiation, with increasing water hardness. For tricationic PSs, the same MEC values were observed for both hydrophilic and amphiphilic porphyrins $(0.78,3.125$, and $6.25 \mu \mathrm{M}$ in DEMI, SW, and HW, respectively). The calculated MEC values for tetracationic PS (TMPyP3) were two or four times higher (3.125 $\mu \mathrm{M}$ in DEMI, $6.25 \mu \mathrm{M}$ in SW, and $12.5 \mu \mathrm{M}$ in HW) in comparison to the MEC values obtained for TMPyP3- $\mathrm{CH}_{3}$ and TMPyP3$\mathrm{C}_{17} \mathrm{H}_{35}$. In our previous work, where L. pneumophila $130 \mathrm{~b}$ strain was used, it was shown that in the tap water of Rijeka (considered as SW in this work) the calculated MEC for TMPyP3- $\mathrm{C}_{17} \mathrm{H}_{35}$ was in a nanomolar scale $(0.024 \mu \mathrm{M})$ [19]. A somewhat dark toxicity in DEMI was also observed, with the MEC value of $3.125 \mu \mathrm{M}$ for both TMPyP3- $\mathrm{CH}_{3}$ and 
TMPyP3- $\mathrm{C}_{17} \mathrm{H}_{35}$ and $6.25 \mu \mathrm{M}$ for TMPyP3. Additionally, a low MEC concentration without irradiation was observed for TMPyP3- $\mathrm{C}_{17} \mathrm{H}_{35}$ in soft water $(6.25 \mu \mathrm{M})$. This is in agreement with our previous work, where the strongest dark toxicity in tap water was also reported for amphiphilic TMPyP3- $\mathrm{C}_{17} \mathrm{H}_{35}(1.56 \mu \mathrm{M})$ [19].
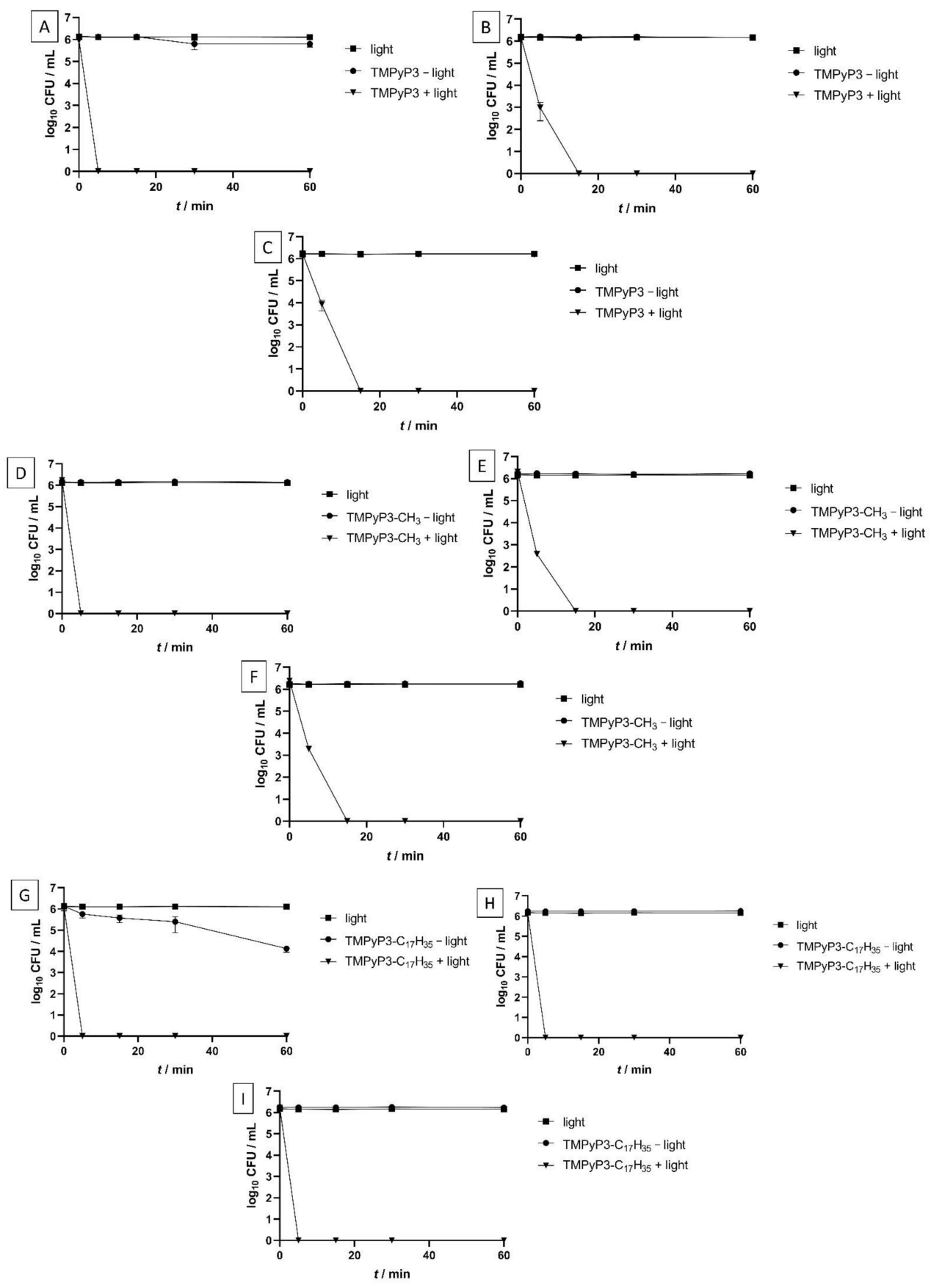

Figure 7. Photoinactivation studies of TMPyP3 (A (DEMI), B (SW), C (HW)), TMPyP3-CH 3 (D (DEMI), E (SW), F (HW)), and TMPyP3- $\mathrm{C}_{17} \mathrm{H}_{35}(\mathrm{G}(\mathrm{DEMI}), \mathbf{H}(\mathrm{SW}), \mathbf{I}(\mathrm{HW}))$ in $0.5 \times$ MEC concentrations. The samples were irradiated for $60 \mathrm{~min}$ with violet light ( $395 \mathrm{~nm}$, total light dose (after $60 \mathrm{~min}$ irradiation) $72 \mathrm{~J} / \mathrm{cm}^{2}$ ). "PS-light" represents dark control, while "light" represents bacteria irradiated with light without presence of PS. All data are presented as an average \pm SD.

PDI was studied using PS concentration $0.5 \times$ MEC determined in SW under irradiation for each PS, which was $1.563 \mu \mathrm{M}$ for TMPyP3- $\mathrm{CH}_{3}$ and TMPyP3- $\mathrm{C}_{17} \mathrm{H}_{35}$ and $3.125 \mu \mathrm{M}$ for TMPyP3. 
For porphyrins TMPyP3 and TMPyP3- $\mathrm{CH}_{3}$, it was shown that $100 \%$ of the bacteria were photoinactivated after 5 min of illumination with violet light $\left(395 \mathrm{~nm}, 20 \mathrm{~mW} / \mathrm{cm}^{2}\right.$, light dose $6 \mathrm{~J} / \mathrm{cm}^{2}$ ) in DEMI, and complete inactivation was achieved after $15 \mathrm{~min}$ in SW and $\mathrm{HW}$ (Figure 7). Except for TMPyP3- $\mathrm{C}_{17} \mathrm{H}_{35}$, there was no visible effect on bacteria in all water samples when a PS was used without photoactivation or when only light was applied, even after irradiation for $60 \mathrm{~min}$ (total light dose $72 \mathrm{~J} / \mathrm{cm}^{2}$ ).

Amphiphilic PS, TMPyP3- $\mathrm{C}_{17} \mathrm{H}_{35}$, showed complete photoinactivation of L. pneumophila already after 5 min under irradiation $\left(6 \mathrm{~J} / \mathrm{cm}^{2}\right)$ in all water samples. In a "light" control, where bacteria were irradiated with violet light without PS, no effect on bacteria was observed. However, in a "dark" control where L. pneumophila was treated with TMPyP3- $\mathrm{C}_{17} \mathrm{H}_{35}$ without irradiation, in DEMI, a $30 \%$ decrease in $\log _{10} \mathrm{CFU} / \mathrm{mL}$ was shown (Figure 7G). In SW and HW, "dark" toxicity of TMPyP3- $\mathrm{C}_{17} \mathrm{H}_{35}$ was not observed (Figure $7 \mathrm{H}, \mathrm{I})$.

\subsection{Impact of PDI Activity on L. pneumophila Adhesion to Polystyrene}

To investigate the effects of the PDI on Legionella biofilm using our porphyrin-type cationic PSs, we performed experiments of the adhesion of L. pneumophila on polystyrene, biofilm formation, and biofilm destruction. The first experiment included testing the impact of irradiation and water hardness on Legionella adhesion to polystyrene. We could observe that light has a small, almost negligible positive impact on the adhesion of L. pneumophila. Moreover, it could be seen that the presence and the number of dissolved ions can increase the number of colonies in the sample. The number of adherent bacteria, in an irradiated sample, was significantly higher in HW in comparison to the sample in SW and DEMI (Figure 8).

The impact of PDI on adhesion to polystyrene was tested in $0.25 \times$ and $0.5 \times \mathrm{MEC}$ concentrations determined for each porphyrin in SW. TMPyP3- $\mathrm{C}_{17} \mathrm{H}_{35}$ in concentration $0.25 \times$ MEC showed 100\% inactivation of the adhesion in DEMI, while TMPyP3-CH showed $\sim 30 \%$ decrease in comparison to control (Figure 9B,C). Negligible difference in DEMI was observed for TMPyP3 (Figure 9A). Additionally, somewhat "dark toxicity" was detected in DEMI for porphyrins TMPyP3- $\mathrm{CH}_{3}$ and TMPyP3- $\mathrm{C}_{17} \mathrm{H}_{35}$, with a decrease of $1 \log _{10} \mathrm{CFU} / \mathrm{mL}$ in concentration $0.25 \times \mathrm{MEC}$ (Figure 9B,C). In SW and HW, a similar PDI effect was shown in both water samples for TMPyP3- $\mathrm{C}_{17} \mathrm{H}_{35}$, where the decrease was $\sim 30 \%$. A negligible decrease in comparison to the "light" control was observed for porphyrin TMPyP3-CH 3 in SW and HW. In SW, porphyrin TMPyP3 showed complete inactivation of the adhesion, while in $\mathrm{HW}, \sim 50 \%$ decrease was observed (Figure 9A).

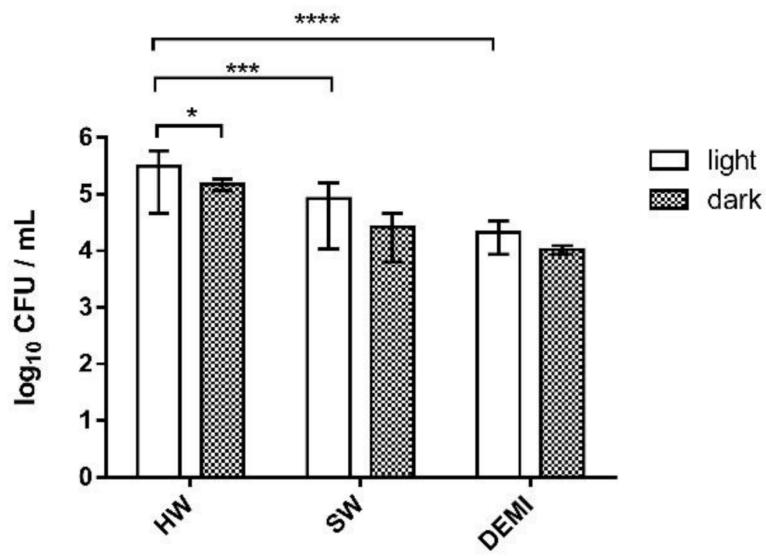

Figure 8. Adhesion of L. pneumophila to polystyrene in water samples of different hardness (HW, SW, and DEMI) after irradiation with violet light for $10 \mathrm{~min}\left(395 \mathrm{~nm}\right.$, total light dose $\left.12 \mathrm{~J} / \mathrm{cm}^{2}\right)(=$ "light") and without irradiation (="dark"). All results are shown as an average of triplicate measurements and error bars presenting SD; ${ }^{* * *} p<0.0001,{ }^{* * *} 0.0001<p<0.001,{ }^{*} 0.01<p<0.05$. 

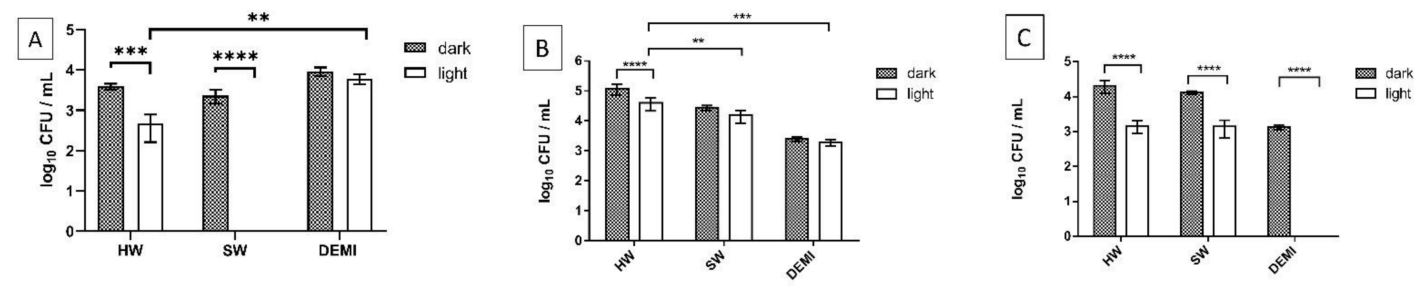

Figure 9. Impact of the PDI on adhesion of L. pneumophila to polystyrene in different water samples (DEMI, SW, HW) by using TMPyP3 (A), TMPyP3- $\mathrm{CH}_{3}(\mathbf{B})$ and TMPyP3- $\mathrm{C}_{17} \mathrm{H}_{35}(\mathbf{C})$ in concentration $0.25 \times$ MEC determined in SW $(0.782 \mu \mathrm{M}$ for TMPyP3- $\mathrm{CH}_{3}$ and TMPyP3- $\mathrm{C}_{17} \mathrm{H}_{35}, 1.563 \mu \mathrm{M}$ for TMPyP3), after irradiation for 10 min with violet light (395 $\mathrm{nm}$, total light dose $12 \mathrm{~J} / \mathrm{cm}^{2}$ ). Treatment with PSs without irradiation was used as a "dark" control. All data are presented as mean $\pm \mathrm{SD} ;{ }^{* * * *} p<0.0001,{ }^{* * *} 0.0001<p<0.001,{ }^{* *} 0.001<p<0.01$.

In a concentration of $0.5 \times \mathrm{MEC}$, a complete inactivation of adhesion was shown for all tested porphyrins in DEMI and SW, while in $\mathrm{HW}$, a $\sim 50 \%$ decrease was observed for porphyrin TMPyP3- $\mathrm{CH}_{3}$ and a $100 \%$ inactivation was observed for PSs TMPyP3- $\mathrm{C}_{17} \mathrm{H}_{35}$ and TMPyP3. A complete inactivation without light irradiation, "dark toxicity", was observed for all porphyrins in DEMI (Figure S7).

\subsection{Impact of PDI Activity on L. pneumophila Biofilm Formation}

The impact of PDI activity was also investigated on early-stage biofilm, i.e., on biofilm formation. Firstly, we tested the impact of light and dissolved minerals in water on biofilm formation, and no difference could be observed between irradiated and nonirradiated samples and between water samples of different hardness. The only difference could be seen on the sample irradiated in DEMI, where a 1-log decrease was detected (Figure 10).

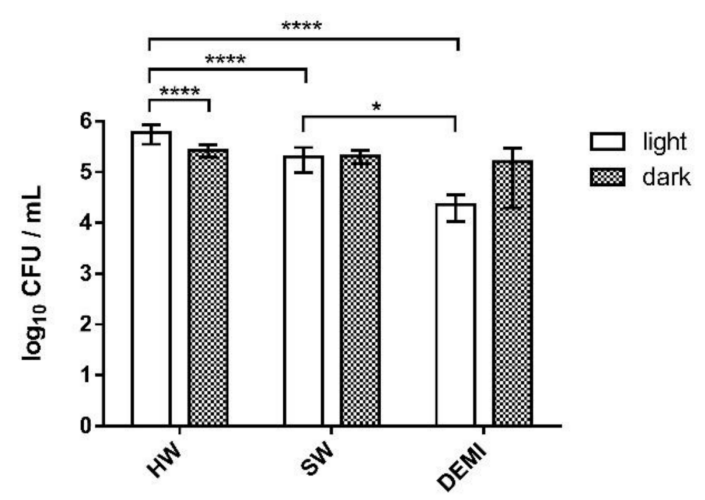

Figure 10. L. pneumophila biofilm formation in water samples of different hardness (HW, SW, and DEMI) with (="light") and without irradiation (="dark"). For the samples that were illuminated, an LED-based source of violet light was used for $10 \mathrm{~min}$ treatment $\left(395 \mathrm{~nm}\right.$, total light dose $\left.12 \mathrm{~J} / \mathrm{cm}^{2}\right)$. All data are presented as an average $\pm \mathrm{SD} ;{ }^{* * *} p<0.0001, * 0.01<p<0.05$.

The tested PSs showed also a high PDI efficiency on L. pneumophila biofilm formation. PDI with tetracationic TMPyP3 resulted in a complete eradication of L. pneumophila earlystage biofilm in DEMI, already in concentration $1 / 4 \times$ MEC. However, in SW $\sim 60 \%$ was inactivated, while in HW a negligible inactivation $(<1-\log$ decrease) was observed (Figure $11 \mathrm{~A})$. In the concentration of $1 / 2 \times \mathrm{MEC}$, the activity of TMPyP3 in HW increased, which led to a decrease in $\log _{10} \mathrm{CFU}$ for $>50 \%$ (Figure S8A). A small dark toxicity was observed for TMPyP3 in concentration $1 / 4 \times$ MEC, especially in SW with a $>2$-log decrease in comparison to biofilm that was kept in the dark or biofilm that was irradiated with violet light for $10 \mathrm{~min}$ (Figure 10, SW). In DEMI and HW, the observed dark toxicity was lower ( 1-log decrease) in comparison to SW (Figure 11A). With TMPyP3 in a concentration of $1 / 2 \times$ MEC, a strong dark toxicity was observed in both SW and DEMI, decreasing the number of bacteria by $>50 \%$ (Figure $\mathrm{S} 8 \mathrm{~A}$ ). 

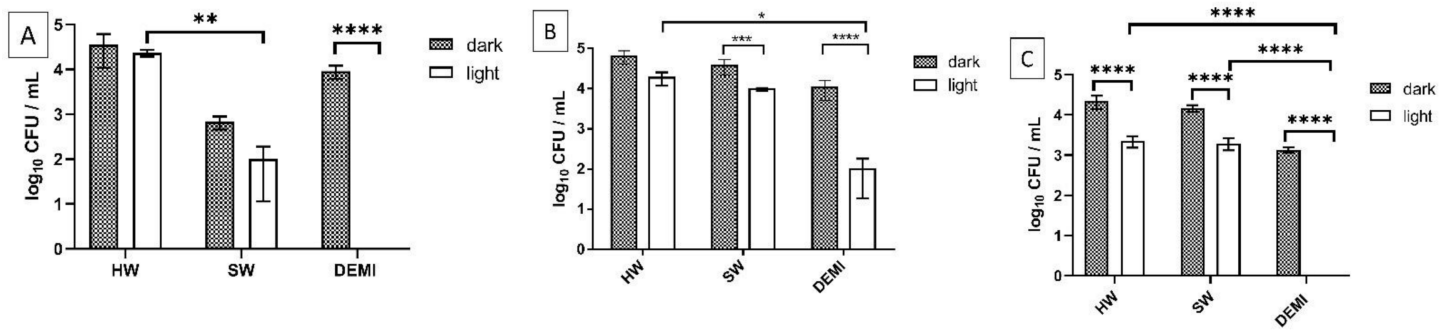

Figure 11. Impact of the PDI on L. pneumophila biofilm formation in different water samples (DEMI, SW, HW) by using TMPyP3 (A), TMPyP3- $\mathrm{CH}_{3}(\mathbf{B})$, and TMPyP3- $\mathrm{C}_{17} \mathrm{H}_{35}(\mathbf{C})$ in concentration $0.25 \times$ MEC determined in SW $(0.782 \mu \mathrm{M}$ for TMPyP3- $\mathrm{CH}_{3}$ and TMPyP3- $\mathrm{C}_{17} \mathrm{H}_{35}, 1.563 \mu \mathrm{M}$ for TMPyP3), after irradiation for 10 min with violet light (395 $\mathrm{nm}$, total light dose $12 \mathrm{~J} / \mathrm{cm}^{2}$ ). The treatment with PSs without irradiation was used as a "dark" control. All data are presented as mean $\pm \mathrm{SD} ;{ }^{* * *} p<0.0001, * * * 0.0001<p<0.001,{ }^{* *} 0.001<p<0.01, * 0.01<p<0.05$.

A complete inactivation occurred in DEMI after the treatment with TMPyP3- $\mathrm{C}_{17} \mathrm{H}_{35}$ (Figure 11C). In HW and SW, a similar effect with a $40 \%$ decrease after the treatment with $1 / 4 \times$ MEC was observed. Interestingly, after increasing the concentration of the TMPyP3- $\mathrm{C}_{17} \mathrm{H}_{35}$ to $1 / 2 \times$ MEC, a complete deactivation of the biofilm formation occurred in SW, while a negligible impact was shown in HW (Figure S8C). Additionally, a complete inactivation without illumination, i.e., dark toxicity, was observed after the treatment with $1 / 2 \times$ MEC of TMPyP3- $\mathrm{C}_{17} \mathrm{H}_{35}$ in DEMI (Figure S8C).

TMPyP3- $\mathrm{CH}_{3}$ in $1 / 4 \times$ MEC concentration showed a 3-log decrease in DEMI, while in SW and HW, the PDI did not result in such a strong effect against biofilm formation (Figure 11B). In concentration $1 / 2 \times \mathrm{MEC}$, a complete inactivation of the biofilm formation occurred in DEMI and SW water, while in HW, a 1-log decrease was shown after irradiation. A strong dark toxicity was observed in DEMI (Figure S8B).

\subsection{L. pneumophila Biofilm Destruction in Different Water Hardness}

As in the experiments of the adhesion and biofilm formation, we also tested the impact of light and water hardness on formed L. pneumophila biofilm. We could observe that water hardness has a small impact on L. pneumophila biofilm growth, the difference being lower than $0.5 \mathrm{log}$. Additionally, $10 \mathrm{~min}$ light irradiation did not show an impact on L. pneumophila biofilm growth (Figure 12).

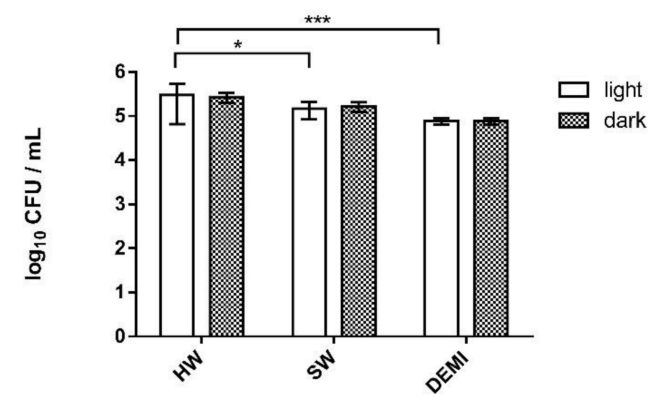

Figure 12. Impact of water hardness (HW, SW, and DEMI) and violet light irradiation on L. pneumophila biofilm. For the light treatments, irradiation with violet light was used for $10 \mathrm{~min}$ (395 nm, total light dose $12 \mathrm{~J} / \mathrm{cm}^{2}$ ). Results are presented as an average with SD on error bars; *** $0.0001<p<0.001, * 0.01<p<0.05$.

PDI activity was tested in concentrations $1 \times$ MEC and $2 \times$ MEC of PSs against L. pneumophila biofilm. A strong impact was observed already at $1 \times$ MEC concentrations for all PSs in DEMI where $100 \%$ of the biofilm was destroyed (Figure 13). No biofilm could be detected after the treatment with light and TMPyP3 in $1 \times$ MEC concentration in all water samples (HW, SW, and DEMI) (Figure 13A). Interestingly, TMPyP3- $\mathrm{CH}_{3}$ showed stronger activity on L. pneumophila biofilm in comparison to the amphiphilic analog by 
showing a complete inactivation in SW and a $>50 \%$ decrease in HW (Figure 13B). In contrast, TMPyP3- $\mathrm{C}_{17} \mathrm{H}_{35}$ showed a 2.5-log decrease after the treatment in SW and a 2-log decrease in HW (Figure 13C).
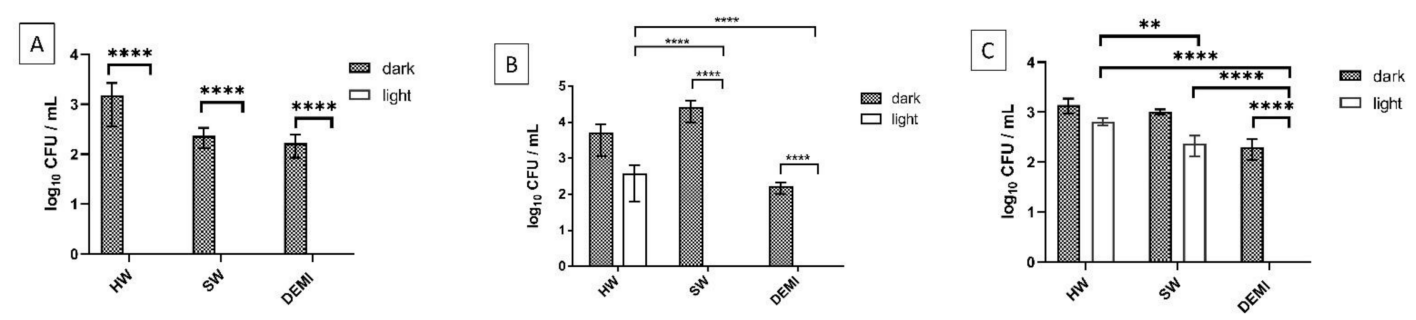

Figure 13. Destruction of the L. pneumophila biofilm with PDT using TMPyP3 (A), $\mathrm{TMPyP}_{3}-\mathrm{CH}_{3}$ (B), and $\mathrm{TMPyP}_{3}-\mathrm{C}_{17} \mathrm{H}_{35}$ (C) in concentration $1 \times$ MEC determined in SW (3.125 $\mu \mathrm{M}$ for TMPyP3- $\mathrm{CH}_{3}$ and TMPyP3- $\mathrm{C}_{17} \mathrm{H}_{35}, 6.250 \mu \mathrm{M}$ for TMPyP3). For the light treatments, irradiation with violet light was used for $10 \mathrm{~min}\left(395 \mathrm{~nm}\right.$, total light dose $\left.12 \mathrm{~J} / \mathrm{cm}^{2}\right)$. "Dark" control represents the treatments with PSs, without irradiation. Results are presented as an average with SD on error bars; **** $p<0.0001,{ }^{* *} 0.001<p<0.01$.

An improved activity in $2 \times$ MEC concentration was only shown after the treatment with TMPyP3- $\mathrm{C}_{17} \mathrm{H}_{35}$ in SW where complete destruction of the biofilm occurred. Moreover, dark toxicity with complete destruction of the biofilm for all porphyrins in $2 \times$ MEC concentration in DEMI was observed (Figure S9).

It is generally accepted that the number of positive charges can increase the activity against Gram-negative bacteria; however, we must point out here that the $2 \times$ higher concentration of symmetrical, tetracationic TMPyP3 in comparison to both asymmetric, tricationic porphyrins may play a role in the observed higher antibacterial activity in all the treatments on biofilm adhesion, biofilm formation, and the destruction of biofilm. As in our previous studies, between the two tricationic porphyrins, amphiphilic TMPyP3- ${ }_{17} \mathrm{H}_{35}$ with a long alkyl chain proved to be more active than hydrophilic TMPyP3- $\mathrm{CH}_{3}$, except in the destruction of the formed biofilm in the presence of minerals, which may be related to the demonstrated reduced photostability of TMPyP3- $\mathrm{C}_{17} \mathrm{H}_{35}$ in $\mathrm{SW}$ and $\mathrm{HW}$.

Our results showed that water hardness does not strongly affect Legionella biofilm or biofilm formation; however, a small increase proportional to the amount of dissolved minerals in water can be observed both in the samples irradiated with violet light and the samples kept in the dark. As we mentioned at the beginning, calcium, magnesium, and organic carbon can increase the number of Legionella in the water and increase the adherence to various surfaces [17]. Bargellini and collaborators investigated the impact of various metal traces, hot water, and heterotrophic plate counts on Legionella contamination and growth. In accordance with our results, they concluded that water hardness does not have an impact on Legionella growth; however, water hardness can increase Legionella occurrence in water samples [32].

Various PSs have been tested as PDI agents in the destruction of biofilms. As an example, a phenothiazinic PS, methylene blue O (MBO), in ethanol formulation showed high Pseudomonas aeruginosa biofilm destruction [33]. Another example is erythrosinemediated PDI against Acetobacter baumannii, a bacterium that can cause various skin infections and ventilator-associated pneumonia. It was shown that erythrosine alone did not affect the A. baumannii biofilm; however, in a combination with acetic acid and chitosan, it was considered a promising therapy [34]. Additionally, Rose Bengal (RB) and a fullerene were tested against two isolates of Enterococcus faecium and E. faecalis, Gram-positive bacteria that can cause various infections [35].

Porphyrin PSs have been widely tested in the treatment of Pseudomonas aeruginosa, another Gram-negative OPPP. Orlandi et al. recently tested the effects of a group of 13 diaryl porphyrins on biofilm formation and eradication of biofilm mass [36]. It was shown that diaryl porphyrins bearing two positively charged pyridyl groups on the opposite side of the porphyrin core have the highest antibiofilm properties and can inhibit the biofilm 
formation and have a mild effect on the formed biofilm [36]. The authors presumed that the highest antibiofilm properties are due to the positive charge of the pyridyl groups being delocalized and directly coordinated with the tetrapyrrole system of porphyrin. Another work, by Patel et al., confirms the importance of cationic groups in the molecular structure in eradicating $P$. aeruginosa biofilms by using $5,10,15$-tris ( $N$-methyl pyridyl)20-pentafluoro phenyl porphyrinatozincTris-4-methylbenzenesulfonate (ZnPor) for PDI. ZnPor in concentrations $16 \mu \mathrm{g} / \mathrm{mL}$ showed a high impact on the eradication of the $10-16 \mathrm{~h}$ old biofilm and on the detachment of the matrix [37].

\section{Materials and Methods}

\subsection{Porphyrins Used as PSs}

The porphyrins used in this work are tetracationic TMPyP3 and two tricationic porphyrins, TMPyP3- $\mathrm{CH}_{3}$ and TMPyP3- $\mathrm{C}_{17} \mathrm{H}_{35}$, that were previously synthesized by our group [19].

\subsection{Water Samples}

The water samples used in this work were taken in Croatia, Međimurska County, from water wells in Prelog and Nedelišće. The water samples were taken before the treatment of water conditioning, and no additional treatments were done prior to the use. The physicochemical properties of the water samples were determined by the laboratory Međimurske Vode d.o.o. (in Čakovec, Croatia) and using portable HQ30D Flexi meter with changing probes for measuring conductivity, $\mathrm{pH}$, and dissolved oxygen concentration (Hach, Loveland, CO, USA). In this work, we used the terms soft water (SW) and hard water (HW) for water samples from water wells Prelog and Nedelišce, respectively, based on the ion concentration and water conductivity. In addition to water samples from the wells, demineralized water (DEMI) was also used (Table 1).

Water samples without further purification were used in the experiments to determine the spectroscopic properties, the photostability of the compounds, and the amount of singlet oxygen produced by PDT. For in vitro biological experiments, all water samples were sterilized by filtration through FilterBio Sterile Syringe Filter (Budapest, Hungary, $0.45 \mu \mathrm{M}, 25 \mathrm{~mm}$ ) prior to their use. Sterile tap water (autoclaved at $121^{\circ} \mathrm{C}$ for $15 \mathrm{~min}$, cooled to at $25^{\circ} \mathrm{C}$, and stored at $4{ }^{\circ} \mathrm{C}$ ), was used for rinsing and preparing 10 -fold serial dilutions for determining the number of cultivable bacteria.

\subsection{Light Sources}

The LED-based sources of violet light used in this work were constructed and calibrated at the Center of Excellence for Advanced Materials and Sensors at the Ruđer Bošković Institute, Zagreb, Croatia. For singlet oxygen detection and photostability measurements, a light source at $411 \mathrm{~nm}$ with fluence rates of $3.5,7$, and $11 \mathrm{~mW} / \mathrm{cm}^{2}$ was used. A light source for irradiation at $395 \mathrm{~nm}$ and fluence rate of $20 \mathrm{~mW} / \mathrm{cm}^{2}$ was used in all biological in vitro experiments testing PDI against L. pneumophila and biofilm formation.

\subsection{Spectroscopic Properties}

For spectroscopic analysis, stock solutions of the PSs were prepared in DEMI $(\sim 100 \mu \mathrm{M})$ and diluted in DEMI, SW, or HW to final, tested concentrations. UV-Vis measurements were performed on Cary 60 spectrophotometer, and for fluorescence measurements, Cary Eclipse was used (Agilent Technologies, Santa Clara, CA, USA). The wavelength span for UV-Vis was from 350 to $500 \mathrm{~nm}$ and for fluorescence measurements was from 550 to $800 \mathrm{~nm}$. The Soret band wavelength of each PS was used as the excitation wavelength for fluorescence measurements.

\subsection{Photostability Measurements}

The photostability of the PSs was measured as a decrease in the Soret band intensity over 5 days. Stock solutions of porphyrins were prepared in DEMI $(\sim 2 \mathrm{mM})$ and diluted in 
HW, SW, or DEMI to the final concentration. The first test (T1) consisted of illuminating the porphyrin solution $(10 \mu \mathrm{M})$ with violet light for 10 min every $24 \mathrm{~h}$ for 5 days (411 nm; fluence rate: $11 \mathrm{~mW} / \mathrm{cm}^{2}$; total light dose: $\left.33 \mathrm{~J} / \mathrm{cm}^{2}\right)$, while in the second test (T2), porphyrin solutions (also $10 \mu \mathrm{M}$ ) were illuminated only on the first day for $10 \mathrm{~min}$ (411 nm; fluence rate: $11 \mathrm{~mW} / \mathrm{cm}^{2}$, total light dose: $\left.6.6 \mathrm{~J} / \mathrm{cm}^{2}\right)$. Detection time points were at 0,5 , and 10 min of irradiation. Between the illumination sections and the absorbance measurements, samples were kept in dark at room temperature. Dark control was obtained for porphyrin solutions in all 3 types of water by keeping the solutions in dark at room temperature all the time and measuring a decrease in the Soret band intensity every $24 \mathrm{~h}$ for 5 days.

\subsection{Singlet Oxygen $\left({ }^{1} \mathrm{O}_{2}\right)$ Detection}

Singlet oxygen production was evaluated by measuring the relative photodegradation of 9,10-anthracenediyl-bis(methylene)dimalonic acid (ABMDMA) (Alfa Aesar, Ward Hill, MA, USA), a commercially available fluorescent probe. In the presence of singlet oxygen, ABMDMA reacts via [4 + 2] Diels-Adler reaction and forms a nonfluorescent endoperoxide product. Relative fluorescence decrease was used for being proportional to the formation of the endoperoxide product, as corresponding to the amount of produced singlet oxygen.

Stock solutions of porphyrins and ABMDMA were prepared in DMSO (1 mM) (Sigma Aldrich, St. Louis, MO, USA), due to lack of solubility of ABMDMA in DEMI, and then dissolved in different water samples to final concentrations. Porphyrins in $1 \mu \mathrm{M}$ concentration and $5 \mu \mathrm{M}$ ABMDMA solution were mixed in ratio 1:1 and transferred to a $1 \mathrm{~cm}$ quartz cuvette (Hellma Analytics, Müllheim, Germany). The solution was irradiated for $10 \mathrm{~min}$ (411 nm; fluence rates $3.5,7$, and $11 \mathrm{~mW} / \mathrm{cm}^{2}$ with final light doses of 2.1, 4.2, and $6.6 \mathrm{~J} / \mathrm{cm}^{2}$, respectively) at room temperature under constant stirring. Fluorescence decrease was measured at $431 \mathrm{~nm}$ every $60 \mathrm{~s}$. ABMDMA in different water samples without the PSs was used as a control. All measurements were performed in duplicate.

Results were presented as a percentage (\%) of fluorescence decrease by calculating area under the curve $(A U C)$ of measured decay according to the following formula:

$$
A U C=\frac{\left(\left(\frac{A}{A 0}\right) s+\left(\frac{A}{A 0}\right) f\right)}{2 \times(t 2-t 1)}
$$

AUC-area under the curve;

$\frac{A}{A 0} s$-ratio of the initial absorbance at beginning of the $60 \mathrm{~s}$ interval;

$\frac{A}{A 0} f$-ratio of the initial absorbance at the end of the $60 \mathrm{~s}$ interval;

t2-time at the end of the interval;

t1-time at the beginning of the interval.

\subsection{Bacteria Strain and Growth Conditions}

Throughout the conduction of the PDI experiments, the clinical isolate of Legionella pneumophila serogroup 1, strain Philadelphia ST1, was used. The clinical isolate of L. pneumophila was obtained courtesy of Prof. Darja Keše from the University of Ljubljana, Slovenia. The bacteria were stored in $10 \%$ glycerol broth at $-80{ }^{\circ} \mathrm{C}$ and routinely cultured on buffered yeast extract agar (BCYE) (Oxoid, Altrincham, UK) for 3-5 days at $35 \pm 2{ }^{\circ} \mathrm{C}$. Once cultured on BCYE, the bacteria were resuspended in sterile deionized water. The optical density at $600 \mathrm{~nm}\left(\mathrm{OD}_{600}\right)$ was measured for the prepared bacterial suspension to adjust the concentration of the stock suspension to approximately $1 \times 10^{9} \mathrm{CFU} / \mathrm{mL}\left(\mathrm{OD}_{600}\right.$ measured 1 corresponded to $1 \times 10^{9} \mathrm{CFU} / \mathrm{mL}$ ). The concentrations of working suspensions $\left(1.0 \times 10^{6} \mathrm{CFU} / \mathrm{mL}\right)$ in water samples of different hardness were adjusted by preparing 10 -fold serial dilutions. The results of the PDI studies were acquired by determining the number of cultivable bacteria in 10-fold serial dilutions on BCYE agar. 


\subsection{Determining Minimum Effective Concentration (MEC) of the PSs in Water Samples of Different Hardness}

The MEC values for TMPyP3- $\mathrm{C}_{17} \mathrm{H}_{35}$, TMPyP3- $\mathrm{CH}_{3}$, and TMPyP3 were obtained using a microdilution technique in deionized water, soft water (SW), and hard water (HW). Methods used to determine MEC and PDI activity were previously described [19]. Twofold serial dilutions (50 to $0.049 \mu \mathrm{M}$ ) of the PSs were prepared in sterile 96-well microtiter plates (Syntesis Padova Italy) for each water sample and mixed with equal volumes of $1.0 \times 10^{6} \mathrm{CFU} / \mathrm{mL}$ bacterial suspensions per well. Afterward, bacterial suspensions and 2-fold serial dilutions of the PSs were incubated and mixed at room temperature for $30 \mathrm{~min}$ without light. After incubation in the dark, bacteria in 2-fold serial dilutions were exposed to the light source for $10 \mathrm{~min}\left(395 \mathrm{~nm}\right.$, total light dose $\left.12 \mathrm{~J} / \mathrm{cm}^{2}\right)$. After irradiation, the samples were incubated for $24 \mathrm{~h}$ in the dark at $35 \pm 2{ }^{\circ} \mathrm{C}$, inoculated onto BCYE agar the following day, and incubated for another $3-5$ days at $35 \pm 2{ }^{\circ} \mathrm{C}$. The MEC values were the lowest concentrations of the PSs in each water sample that yielded negative subcultures on BCYE agar. The toxicity of the PSs to bacterial cells in the dark for each water sample was determined following the same procedure, excluding exposure to the light source.

\subsection{PDI Studies in Water Samples of Different Hardness}

The bacterial suspensions $\left(10^{6} \mathrm{CFU} / \mathrm{mL}\right)$ prepared in different water samples were mixed with the PSs also prepared in different water samples $(0.5 \times$ MEC determined for SW: $1.563 \mu \mathrm{M}$ for TMPyP3- $\mathrm{CH}_{3}$ and TMPyP3- $\mathrm{C}_{17} \mathrm{H}_{35}$ and $3.125 \mu \mathrm{M}$ for TMPyP3). After incubation and mixing at room temperature for $30 \mathrm{~min}$ in the dark, the samples were illuminated with violet light $(395 \mathrm{~nm})$ for different periods of time $(0,5,15,30$, and $60 \mathrm{~min}$, corresponding to a total light dose of $0,6,18,36$, and $72 \mathrm{~J} / \mathrm{cm}^{2}$, respectively). Following each of the illumination periods, 10 -fold serial dilutions of the samples were prepared and inoculated onto BCYE agar and incubated for $3-5$ days at $35 \pm 2{ }^{\circ} \mathrm{C}$. After incubation, the number of cultivable bacteria was determined, and the obtained results were presented as survival curves of the bacterium $(\mathrm{CFU} / \mathrm{mL})$ dependent on the total dose of light $\left(0-72 \mathrm{~J} / \mathrm{cm}^{2}\right)$.

\subsection{Antiadhesion and Antibiofilm Properties of the PSs in Water Samples of Different Hardness on Polystyrene}

Equal volumes of the bacterial suspensions $\left(10^{6} \mathrm{CFU} / \mathrm{mL}\right)$ and solutions of the PSs were prepared in the water samples of different hardness and then mixed in sterile 96-well microtiter plates (Syntesis, Padova, Italy). The final concentrations of the PSs, once they were mixed with bacterial suspensions, were $0.5 \times \mathrm{MEC}\left(1.563 \mu \mathrm{M}\right.$ for $\mathrm{TMPyP}_{3}-\mathrm{CH}_{3}$ and TMPyP3- $\mathrm{C}_{17} \mathrm{H}_{35}$ and $3.125 \mu \mathrm{M}$ for TMPyP3 $)$ and $0.25 \times \mathrm{MEC}\left(0.782 \mu \mathrm{M}\right.$ for TMPyP3- $\mathrm{CH}_{3}$ and TMPyP3- $\mathrm{C}_{17} \mathrm{H}_{35}$ and $1.563 \mu \mathrm{M}$ for TMPyP3) determined for SW. The samples were incubated, while stirring, at room temperature for $30 \mathrm{~min}$ without light. After incubation, the samples were irradiated for $10 \mathrm{~min}\left(395 \mathrm{~nm}\right.$; total dose of light $\left.12 \mathrm{~J} / \mathrm{cm}^{2}\right)$ and incubated for $24 \mathrm{~h}$ at $35 \pm 2{ }^{\circ} \mathrm{C}$. The following day, samples were washed 2 times with sterile tap water, and microtiter plates with samples were placed in the ultrasound bath (BandelinBactoSonic, Berlin, Germany) for $1 \mathrm{~min}(p=200 \mathrm{~W}, f=40 \mathrm{kHz})$. After 10-fold serial dilutions of the samples were prepared, the dilutions were inoculated onto BCYE agar and incubated for $3-5$ days at $35 \pm 2{ }^{\circ} \mathrm{C}$. The number of cultivable bacteria was determined after incubation.

A similar procedure was conducted to test the antibiofilm properties of the PSs. The bacterial suspensions $\left(10^{6} \mathrm{CFU} / \mathrm{mL}\right)$ and the porphyrin solutions (final concentration $0.5 \times$ MEC and $0.25 \times$ MEC determined for soft water) were mixed, incubated with stirring at room temperature without light, and irradiated for $10 \mathrm{~min}$. After irradiation, the samples were incubated for 5 days at $35 \pm 2{ }^{\circ} \mathrm{C}$. Following the incubation, samples were washed 2 times with sterile tap water and treated in an ultrasound bath; afterward, 10-fold serial dilutions were prepared. The dilutions were then inoculated onto BCYE agar to determine the number of cultivable bacteria. 


\subsection{Effectiveness of the PSs and Their PDI Activity on Biofilm Destruction in Waters of Different Hardness}

The bacterial suspensions $\left(10^{6} \mathrm{CFU} / \mathrm{mL}\right)$ were placed in sterile $96-$ well microtiter plates (Synthesis, Italy) and incubated for 5 days at $35 \pm 2{ }^{\circ} \mathrm{C}$. After 5 days, biofilm in microtiter plates was washed 2 times with sterile tap water, and solutions of the PSs $\left(1 \times\right.$ MEC $\left(3.125 \mu \mathrm{M}\right.$ for TMPyP3- $\mathrm{CH}_{3}$, and TMPyP3- $\mathrm{C}_{17} \mathrm{H}_{35}$ and $6.250 \mu \mathrm{M}$ for TMPyP3) and $2 \times$ MEC $\left(6.250 \mu \mathrm{M}\right.$ for TMPyP3- $\mathrm{CH}_{3}$, and TMPyP3 and $12.500 \mu \mathrm{M}$ for TMPyP3$\mathrm{C}_{17} \mathrm{H}_{35}$ ) determined for $\mathrm{SW}$ ) were added in wells where biofilm had formed. The bacterial suspensions and the porphyrin solutions were prepared in the water samples of different water hardness. The samples were incubated with stirring for $30 \mathrm{~min}$ at room temperature without light and exposed to the light source for $10 \mathrm{~min}(395 \mathrm{~nm}$, total dose of light $12 \mathrm{~J} / \mathrm{cm}^{2}$ ). After irradiation, the samples were incubated for $24 \mathrm{~h}$ at $35 \pm 2{ }^{\circ} \mathrm{C}$, washed 3 times with sterile tap water, and treated in the ultrasound bath for $1 \min (p=200 \mathrm{~W}$, $f=40 \mathrm{kHz}$ ); then, 10-fold serial dilutions were prepared, inoculated onto BCYE agar, and incubated for $3-5$ days at $35 \pm 2{ }^{\circ} \mathrm{C}$. The number of cultivable bacteria was determined following incubation.

\subsection{Statistics}

The statistical analysis in this work was performed using the program GraphPad Prism 8. All data were presented as average of repeated measurements with standard deviation on error bars. In all experiments, results were analyzed using two-way analysis of variance (ANOVA), where differences were marked as statistically significant if $\alpha<0.05$. Level of significance was presented in four levels: ${ }^{* * * *}(p<0.0001),{ }^{* * *}(0.0001<p<0.001)$, ** $(0.001<p<0.01), *(0.01<p<0.05)$.

\section{Conclusions}

In conclusion, PDI can be used as a treatment for L. pneumophila in waters of different hardness. The highest impact, as in our previous work, was shown with TMPyP3- $\mathrm{C}_{17} \mathrm{H}_{35}$, a tricationic porphyrin with a long alkyl chain. This PS showed the highest singlet oxygen production and PDI activity in all experiments including L. pneumophila biofilm. However, its stability strongly decreases after repeated irradiation cycles and in hard water.

On the other side, tetracationic TMPyP3 also showed a strong impact on L. pneumophila adhesion and biofilm formation and in the destruction of the formed biofilm; however, its MEC value obtained in SW was 2 times higher in comparison to both tricationic porphyrins. Finally, water hardness decreased the efficiency of all porphyrins against L. pneumophila and its biofilm since the highest PDI activity for each of them was observed in DEMI.

The results obtained suggest that the hydrophilic PSs could be used where the PDI action against Legionella biofilm over a long period of time and repetition of illumination is required, while the amphiphilic PS could be used where high efficiency in a short time is required. Since the work presented here is an initial study on the use of PDI to control Legionella biofilm formation in water, further research is needed to investigate these possibilities.

Supplementary Materials: The following are available online at https:/ /www.mdpi.com/article/10 $.3390 /$ ijms22169095/s1.

Author Contributions: Conceptualization, I.G. and N.M.; methodology, I.G., N.M., M.M., and M.L.; formal analysis, M.M., I.Ć., A.L., N.M., and I.G.; investigation, N.M., I.G., M.M., and I.Ć.; validation, all authors; data curation, N.M., I.G., M.M., and I.Ć.; funding acquisition, N.M., I.G., and M.L.; project administration, N.M. and I.G.; resources, N.M., I.G., and M.L.; visualization, N.M., I.G., M.M., and I.Ć.; supervision, N.M. and I.G.; writing-original draft, N.M., M.M., and I.G.; writing-review and editing, N.M., M.M., M.L., and I.G. All authors have read and agreed to the published version of the manuscript.

Funding: This work was financially supported by the University of Rijeka (grant Nos. uniri-biomed18-171 and uniri-prirod-18-173) and ERDF Grant for CEMS No. KK.01.1.1.01.0001. 
Institutional Review Board Statement: Not applicable.

Informed Consent Statement: Not applicable.

Data Availability Statement: The data that support the findings of this study are available from the corresponding author upon reasonable request.

Acknowledgments: We are grateful to Anton Radman from the Laboratory for Photonics and Quantum Optics and coworkers from the Workshop of Physical Chemistry Division at Ruđer Bošković Institute in Zagreb for all the light sources used in this work.

Conflicts of Interest: The authors declare no conflict of interest. The funders had no role in the design of the study; in the collection, analyses, or interpretation of data; in the writing of the manuscript; or in the decision to publish the results.

\section{References}

1. Niculescu, A.-G.; Grumezescu, A.M. Photodynamic Therapy-An Up-to-Date Review. Appl. Sci. 2021, 11, 3626. [CrossRef]

2. $\quad$ Ladeira, B.M.F.; Dias, C.J.; Gomes, A.T.P.C.; Tomé, A.C.; Neves, M.G.P.M.S.; Moura, N.M.M.; Almeida, A.; Faustino, M.A.F. Cationic Pyrrolidine/Pyrroline-Substituted Porphyrins as Efficient Photosensitizers against E. coli. Molecules 2021, $26,464$. [CrossRef]

3. Skwor, T.A.; Klemm, S.; Zhang, H.; Schardt, B.; Blaszczyk, S.; Bork, M.A. Photodynamic inactivation of methicillin-resistant Staphylococcus aureus and Escherichia coli: A metalloporphyrin comparison. J. Photochem. Photobiol. B Biol. 2016, 165, 51-57. [CrossRef]

4. Amos-Tautua, M.B.; Songca, P.S.; Oluwafemi, S.O. Application of Porphyrins in Antibacterial Photodynamic Therapy. Molecules 2019, 24, 2456. [CrossRef]

5. Sobotta, L.; Skupin-Mrugalska, P.; Piskorz, J.; Mielcarek, J. Porphyrinoid photosensitizers mediated photodynamic inactivation against bacteria. Eur. J. Med. Chem. 2019, 175, 72-106. [CrossRef] [PubMed]

6. Street, C.N.; Gibbs, A.; Pedigo, L.; Andersen, D.; Loebel, N.G. In vitro photodynamic eradication of Pseudomonas aeruginosa in planktonic and biofilm culture. Photochem. Photobiol. 2009, 85, 137-143. [CrossRef]

7. Soukos, N.S.; Goodson, J.M. Photodynamic therapy in the control of oral biofilms. Periodontol. 2000 2011, 55, 143-166. [CrossRef]

8. Santin, G.C.; Oliveira, D.S.B.; Galo, R.; Borsatto, M.C.; Corona, S.A.M. Antimicrobial photodynamic therapy and dental plaque: A systematic review of the literature. Sci. World J. 2014, 824538. [CrossRef]

9. Vassena, C.; Fenu, S.; Giuliani, F.; Fantetti, L.; Roncucci, G.; Simonutti, G.; Romanò, C.L.; De Francesco, R.; Drago, L. Photodynamic antibacterial and antibiofilm activity of RLP068/Cl against Staphylococcus aureus and Pseudomonas aeruginosa forming biofilms on prosthetic material. Int. J. Antimicrob. Agents 2014, 44, 47-55. [CrossRef]

10. Dai, T.; Huang, Y.-Y.; Hamblin, M.R. Photodynamic therapy for localized infections-State of the art. Photodiagnosis Photodyn. Ther. 2009, 6, 170-188. [CrossRef]

11. Alves, E.; Costa, L.; Carvalho, C.M.B.; Tomé, J.P.C.; Faustino, M.A.; Neves, M.G.; Tomé, A.C.; Cavaleiro, J.A.S.; Cunha, Â.; Almeida, A. Charge effect on the photoinactivation of Gram-negative and Gram-positive bacteria by cationic meso-substituted porphyrins. BMC Microbiol. 2009, 9, 70. [CrossRef]

12. George, S.; Hamblin, M.R.; Kishen, A. Uptake pathways of anionic and cationic photosensitizers into bacteria. Photochem. Photobiol. Sci. 2009, 8, 788-795. [CrossRef]

13. Falkinham, O.J.; Pruden, A.; Edwards, M. Opportunistic Premise Plumbing Pathogens: Increasingly Important Pathogens in Drinking Water. Pathogens 2015, 4, 373-386. [CrossRef] [PubMed]

14. Fields, B.S.; Benson, R.F.; Besser, R.E. Legionella and Legionnaires' Disease: 25 Years of Investigation. Clin. Microbiol. Rev. 2002, 15, 506-526. [CrossRef] [PubMed]

15. Rogers, J.; Dowsett, A.B.; Dennis, P.J.; Lee, J.V.; Keevil, C.W. Influence of temperature and plumbing material selection on biofilm formation and growth of Legionella pneumophila in a model potable water system containing complex microbial flora. Appl. Environ. Microbiol. 1994, 60, 1585-1592. [CrossRef] [PubMed]

16. van der Kooij, D.; Veenendaal, H.R.; Scheffer, W.J.H. Biofilm formation and multiplication of Legionella in a model warm water system with pipes of copper, stainless steel and cross-linked polyethylene. Water Res. 2005, 39, 2789-2798. [CrossRef]

17. Abdel-Nour, M.; Duncan, C.; Low, D.E.; Guyard, C. Biofilms: The stronghold of Legionella pneumophila. Int. J. Mol. Sci. 2013, 14, 21660-21675. [CrossRef]

18. Abu Khweek, A.; Amer, A.O. Factors Mediating Environmental Biofilm Formation by Legionella pneumophila. Front. Cell. Infect. Microbiol. 2018, 8, 38. [CrossRef]

19. Lesar, A.; Mušković, M.; Begić, G.; Lončarić, M.; Linšak, D.T.; Malatesti, N.; Gobin, I. Cationic porphyrins as effective agents in photodynamic inactivation of opportunistic plumbing pathogen Legionella pneumophila. Int. J. Mol. Sci. 2020, 21, 5367. [CrossRef]

20. Szysz, M.P. Biological Role of Legionella Pneumophila lipopolysaccharide. Biomed. J. Sci. Tech. Res. 2018, 4, 3739-3741. [CrossRef]

21. Herschmann, J.R.; Ali, A.; Harris, M.; McClinton, M.; Zamadar, M. Effect of Toxic Metal Ions on Photosensitized Singlet Oxygen Generation for Photodegradation of Polyaromatic Hydrocarbon Derivatives and Inactivation of Escherichia coli. Photochem. Photobiol. 2019, 95, 823-832. [CrossRef] 
22. Sengupta, P. Potential health impacts of hard water. Int. J. Prev. Med. 2013, 4, 866-875. [PubMed]

23. Malatesti, N.; Harej, A.; Kraljević Pavelić, S.; Lončarić, M.; Zorc, H.; Wittine, K.; Andjelkovic, U.; Josic, D. Synthesis, characterisation and in vitro investigation of photodynamic activity of 5-(4-octadecanamidophenyl)-10,15,20-tris( $N$-methylpyridinium-3yl)porphyrin trichloride on HeLa cells using low light fluence rate. Photodiagnosis Photodyn. Ther. 2016, 15, 115-126. [CrossRef] [PubMed]

24. Gradova, M.A.; Gradov, O.V.; Zhdanova, K.A.; Bragina, N.A.; Lobanov, A.V. Self-assembly of amphiphilic meso-aryl-substituted porphyrin derivatives in the presence of surfactants. J. Porphyr. Phthalocyanines 2019, 24, 505-514. [CrossRef]

25. Entradas, T.; Waldron, S.; Volk, M. The detection sensitivity of commonly used singlet oxygen probes in aqueous environments. J. Photochem. Photobiol. B Biol. 2020, 204, 111787. [CrossRef]

26. Carloni, P.; Damiani, E.; Greci, L.; Stipa, P.; Tanfani, F.; Tartaglini, E.; Wozniak, M. On the use of 1,3-diphenylisobenzofuran (DPBF). Reactions with carbon and oxygen centered radicals in model and natural systems. Res. Chem. Intermed. 1993, 19, 395-405. [CrossRef]

27. Żamojć, K.; Zdrowowicz, M.; Rudnicki-Velasquez, P.B.; Krzymiński, K.; Zaborowski, B.; Niedziałkowski, P.; Jacewicz, D.; Chmurzyński, L. The development of 1,3-diphenylisobenzofuran as a highly selective probe for the detection and quantitative determination of hydrogen peroxide. Free Radic. Res. 2017, 51, 38-46. [CrossRef]

28. Jelovica, M.; Grbčić, P.; Mušković, M.; Sedić, M.; Pavelić, S.K.; Lončarić, M.; Malatesti, N. In Vitro Photodynamic Activity of N-Methylated and N-Oxidised Tripyridyl Porphyrins with Long Alkyl Chains and Their Inhibitory Activity in Sphingolipid Metabolism. ChemMedChem 2018, 13, 360-372. [CrossRef]

29. Schenning, A.P.H.J.; Feiters, M.C.; Nolte, R.J.M. An amphiphilic porphyrin with unexpected aggregation behaviour. Tetrahedron Lett. 1993, 34, 7077-7080. [CrossRef]

30. Rapozzi, V.; Zorzet, S.; Zacchigna, M.; Drioli, S.; Xodo, L.E. The PDT activity of free and pegylated pheophorbide a against an amelanotic melanoma transplanted in C57/BL6 mice. Invest. New Drugs 2013, 31, 192-199. [CrossRef]

31. Sułek, A.; Pucelik, B.; Kobielusz, M.; Barzowska, A.; Dabrowski, J.M. Photodynamic inactivation of bacteria with porphyrin derivatives: Effect of charge, lipophilicity, ros generation, and cellular uptake on their biological activity in vitro. Int. J. Mol. Sci. 2020, 21, 8716. [CrossRef] [PubMed]

32. Bargellini, A.; Marchesi, I.; Righi, E.; Ferrari, A.; Cencetti, S.; Borella, P.; Rovesi, S. Parameters predictive of Legionella contamination in hot water systems: Association with trace elements and heterotropic plate counts. Water Res. 2011, 45, 2315-2321. [CrossRef] [PubMed]

33. Prochnow, E.P.; Martins, M.R.; Campagnolo, C.B.; Santos, R.C.; Villetti, M.A.; Kantorski, K.Z. Antimicrobial photodynamic effect of phenothiazinic photosensitizers in formulations with ethanol on Pseudomonas aeruginosa biofilms. Photodiagnosis Photodyn. Ther. 2016, 13, 291-296. [CrossRef]

34. Fekrirad, Z.; Darabpour, E.; Kashef, N. Eradication of Acinetobacter baumannii Planktonic and Biofilm Cells Through ErythrosineMediated Photodynamic Inactivation Augmented by Acetic Acid and Chitosan. Curr. Microbiol. 2021, 78, 879-886. [CrossRef] [PubMed]

35. Woźniak, A.; Kruszewska, B.; Pierański, M.K.; Rychłowski, M.; Grinholc, M. Antimicrobial photodynamic inactivation affects the antibiotic susceptibility of Enterococcus spp. clinical isolates in biofilm and planktonic cultures. Biomolecules 2021, 11, 693. [CrossRef]

36. Orlandi, V.T.; Martegani, E.; Bolognese, F.; Trivellin, N.; Garzotto, F.; Caruso, E. Photoinactivation of Pseudomonas aeruginosa Biofilm by Dicationic Diaryl-Porphyrin. Int. J. Mol. Sci. 2021, 22, 6808. [CrossRef]

37. Patel, N.; Swavey, S.; Robinson, J. A Cationic Porphyrin, ZnPor, Disassembles Pseudomonas aeruginosa Biofilm Matrix, Kills Cells Directly, and Enhances Antibiotic Activity of Tobramycin. Antibiotics 2020, 9, 875. [CrossRef] [PubMed] 